\title{
Comparison of somatic STAT3 and STAT5b gene mutations between Felty's syndrome and T-cell large granular lymphocytic leukemia with rheumatoid arthritis
}

Vadim R. Gorodetskiy ( $\sim$ gorodetskiyblood@mail.ru )

V.A.Nasonova Research Institute of Rheumatology https://orcid.org/0000-0001-8428-1281

Yulia V. Sidorova

National Research Center for Hematology

Natalia A. Kupryshina

N.N.Blokhin Russian Cancer Research Center

Vladimir I. Vasilyev

Diagnostic center of the MEDSI clinic

Natalya A. Probatova

N.N. Blokhin Russian Cancer Research Center

Natalya V. Ryzhikova

National Research Center for Hematology

Andrey B. Sudarikov

National Research Center for Hematology

Research article

Keywords: Felty's syndrome, Large granular lymphocyte leukemia, Rheumatoid arthritis, STAT3,STAT5b

Posted Date: August 28th, 2020

DOI: https://doi.org/10.21203/rs.3.rs-64791/v1

License: (c) (i) This work is licensed under a Creative Commons Attribution 4.0 International License.

Read Full License 


\section{Abstract}

Objectives Approximately $15 \%$ of patients with T-cell large granular lymphocytic leukemia (T-LGLL) have rheumatoid arthritis (RA). RA-associated T-LGLL with low large granular lymphocyte counts (aleukemic presentation) and Felty's syndrome (FS) have indistinguishable clinical presentations. These disorders are distinguished by T-cell clonality which is observed in T-LGLL but not in FS. Activating somatic mutations in the signal transducer and activator of transcription 3 (STAT3) and 5 (STAT5b) genes are involved in T-LGLL pathogenesis; however, the prevalence of these mutations in FS is unknown.

Methods Based on the rearrangements of T-cell receptor (TCR) gamma and beta genes according to the BIOMED-2 protocol, we examined T-cell clonality in 81 patients with RA and unexplained neutropenia. We stratified these patients by the presence or absence of T-cell clonality, respectively, into 2 groups: RAassociated T-LGLL (56 patients) and FS (25 patients). Allele-specific TaqMan Real-Time polymerase chain reaction assay was employed to detect point somatic mutations in STAT3 and STAT5b genes in each group.

Results Mutations of the STAT3 gene were detected in none of the 24 cases of FS and in 22 of 56 cases of RA-associated T-LGLL $(39 \%)(p<0.001)$. No mutation of the STAT $5 \mathrm{~b}$ gene was detected in any of the patients in each group.

Conclusions Although further data are needed, our results suggest that activating somatic mutations in STAT3 and STAT $5 \mathrm{~b}$ genes are not involved in the pathogenesis of FS.

\section{Introduction}

Currently, Felty's syndrome (FS) is considered an uncommon subset of seropositive rheumatoid arthritis (RA).[1] Persistent unexplained neutropenia (absolute neutrophil counts below $1.5-2.0 \times 10^{9} / \mathrm{L}$ ) is a mandatory criterion for suggesting FS in a patient with RA. Although splenomegaly was one of the triads originally described by Felty, later studies showed that spleen size does not correlate with neutropenia and that patients with RA and neutropenia are like patients with the full triad.[2-4] At present, splenomegaly is not an absolute diagnostic requirement for diagnosing FS.[5, 6] FS is a clinical diagnosis and there is no specific single diagnostic test to confirm or exclude it; therefore, FS is essentially a diagnosis of exclusion. The pathogenesis of FS is unknown.

Large granular lymphocytic leukemia (LGLL) is a rare chronic lymphoproliferative disorder characterized by the expansion of immunophenotypically distinct, clonal, large granular lymphocytes (LGLs). In most cases, LGLL has an immunophenotype of cytotoxic T-lymphocytes (CD3+/CD8+) that co-express NK-cell lineage-associated antigens CD16 and/or CD57, and diminished or absent expression of pan T-cell markers CD5 and/or CD7.[7, 8] Approximately $15 \%$ of patients with T-cell LGLL (T-LGLL) have RA [9, 10]; on the contrary, clonal expansion of LGLs was detected in $3.6 \%$ of patients with RA.[11] T-LGLL is usually diagnosed 10-15 years after the manifestation of RA.[5] A typical manifestation of T-LGLL is neutropenia and splenomegaly detected in up to $84 \%$ and $50 \%$ of patients, respectively.[12] Recent studies on the 
lymphocytes from patients with T-LGLL have shown activating somatic mutations in signal transducer and activator of transcription 3 (STAT3) and 5 (STAT5b) genes in 27-72\% [13-16] and 2\% [17] of all cases, respectively.

T-LGLL with RA resembles FS in many aspects and some researchers hypothesize that RA-associated TLGLL and FS are part of a single disease process with a common pathogenic mechanism. $[5,18,19]$ However, the prevalence of STAT3 and STAT5b mutation status in FS is unknown. In this study, we stratified 81 patients with RA and unexplained neutropenia into 2 groups based on the presence and absence of T-cell clonality (RA-associated T-LGLL and FS), and then examined STAT3 and STAT5b gene mutations in both groups. We also present the clinical and laboratory characteristics of 25 patients with FS and discuss their differential diagnosis with RA-associated T-LGLL.

\section{Patients And Methods}

We diagnosed FS if all three criteria were met: (i) RA diagnosed according to the 2010 American College of Rheumatology/European League Against Rheumatism criteria [20]; (ii) neutropenia (absolute neutrophil counts $<1.5 \times 10^{9} / \mathrm{L}$ ) without an alternative explanation such as drug-induced suppression; (iii) absence of T-cell clonality.

Peripheral blood (PB) smears for LGL counting were re-examined in 18 cases. Bone marrow aspiration with differentiated cell counts was performed in 14 cases and in 11 of these, a bone marrow biopsy was also performed. The collected clinical data included patient age, sex, presence of splenomegaly, RA duration, titers of rheumatoid factor (RF), antibodies against cyclic citrullinated peptides (anti-CCP), antibodies against mutated citrullinated vimentin (anti-MCV), maximal Disease Activity Score derivative for 28 joints calculated using C-reactive protein (max.DAS28-CRP) during follow-up, erosive arthritis, and associated autoimmune diseases.

\section{Flow cytometric analysis}

A four-color flow cytometric analysis was performed on peripheral blood (16 cases), peripheral blood and bone marrow ( 2 cases), and bone marrow (1 case) specimens. Lymphocytes were gated using CD45 versus side scatter dot plots. Cells were stained with a panel of fluorescence-labeled monoclonal antibodies including CD3, CD4, CD5, CD7, CD8, CD16, CD19, CD56, and CD57. Flow cytometry analysis was performed on a BD FACSCanto ${ }^{T M}$ II (Becton Dickinson, San Jose, CA, USA) using FCS express Version 3 (De Novo Software, Los Angeles, CA) software.

\section{Immunohistochemical studies}

Immunohistochemical studies were carried out for 6 cases using sections of decalcified paraffinembedded bone marrow biopsy specimens. The following antibodies were used at the dilutions suggested by the manufacturers: CD3 (Polyclonal, Dako), CD4 (clone 4B12, Dako), CD 8 (clone C8/144B, Dako), CD20 (clone L26, Dako), CD56 (clone 123C3, Dako), CD57 (clone TB01, Dako), granzyme B (clone 
GrB-7, Dako), and TIA1 (clone 2G9, Immunotech, France). After dewaxing and heat-induced antigen retrieval, immunostaining was performed on an Autostainer Link 48 (Dako, Denmark) according to the manufacturer's instructions. All immunostained samples were counterstained with hematoxylin.

\section{Evaluation of STAT3 and STAT5b gene mutations and T-cell clonality}

STAT3 and STAT5 $b$ gene mutations and T-cell clonality were examined using genomic DNA extracted from blood (17 patients), blood and bone marrow (5 patients), bone marrow (1 patient), blood and spleen (1 patient), and blood, bone marrow and spleen tissue (1 patient) samples.

Evaluation of T-cell clonality was based on the rearrangements of the T-cell receptor (TCR) gamma ( $\mathrm{VY}^{-}$ $J Y)$ and TCR beta $(V \beta-J \beta, D \beta-J \beta)$ genes. T-cell clonality assays were performed according to the BIOMED-2 standardized protocol.[21] Polymerase chain reaction (PCR) was carried out using an automated DNA Engine thermocycler (BioRad, Hercules, USA), and fragments were detected using an ABI PRISM 3130 Genetic Analyzer (Applied Biosystems, Foster City, CA); the data were analyzed using GeneMapper software version 4.0 (Applied Biosystems, Foster City, CA).

Allele-specific (AS) TaqMan Real-Time PCR assays were employed to determine the somatic point mutations in STAT3 (p.Y640F; p.N647l; p.D661V; p.D661Y; p.D661H; p.D661N) and STAT5b (p.N642H) genes. DNA (200-400 ng) was added to $25 \mu \mathrm{L}$ of the reaction mixture containing 10 pmol of WT (wild type)-specific or MT (mutated type)-specific forward primer, $10 \mathrm{pmol}$ of common reverse primer, and $7.5 \mathrm{pmol}$ of the fluorescent probe. AS-PCR was then performed in triplicate (3 WT + $3 \mathrm{MT}$ ) using a StepOne Real-Time PCR System (Applied Biosystems, USA). PCR conditions included preliminary denaturation at $95^{\circ} \mathrm{C}$ for $5 \mathrm{~min}$, followed by 45 cycles at $95^{\circ} \mathrm{C}$ for $30 \mathrm{~s}, 62^{\circ} \mathrm{C}$ for $30 \mathrm{~s}$, and $72{ }^{\circ} \mathrm{C}$ for $30 \mathrm{~s}$. A mixture of DNA from healthy donors was used as a negative control. Samples with mutations confirmed by Sanger sequencing were used as positive controls. The primer and probe sequences are shown in Supplement 1. As a comparison group, we tested the STAT3 and STAT5b mutational status in 56 patients with T-LGLL in the context of RA.

\section{Statistical analysis}

Fisher's two-tailed test was used to compare the frequency of STAT3 mutations between the groups of patients with FS and RA-associated T-LGLL.

\section{Results}

We stratified 81 patients with RA and neutropenia according to the presence and absence of T-cell clonality, respectively, into 2 groups: RA-associated T-LGLL (56 patients) and FS ( 25 patients). The clinical and biological characteristics of $25 \mathrm{FS}$ patients are presented in Table 1 and in Supplementary Table 1. Seven of the 25 (28\%) patients also had a concomitant autoimmune condition: 6 patients had Sjogren syndrome (SS) and one patient had SS and autoimmune thyroiditis. Nineteen of the 25 (76\%) patients were females. The median age at FS diagnosis was 54 years (range, 30-79 years). The median duration 
of RA prior to FS diagnosis was 7 years (range, $0-35$ years). The median maximum RA activity over the observation period, estimated by DAS28, was 4.9 (range, 2.1-7.01). Erosive arthritis at FS diagnosis was detected in 16 of 22 (73\%) of patients. RF was positive in 23 of $25(92 \%)$ patients; however, 2 of these 23 RF-positive patients had low RF levels (less than 2 normal ranges). The median RF level was $332.7 \mathrm{IU} / \mathrm{mL}$ (range, 9.5-12900.0 IU/mL). Anti-CCP was positive in 23 of $24(96 \%)$ patients. Anti-MCV was positive in all 11 patients examined. In all 4 RF-negative and weakly positive patients, the anti-CCP and anti-MCV titers were highly positive. The median neutrophil count was $0.496 \times 10^{9} / \mathrm{L}$ with a range of $0.052-1224.0$ $\times 10^{9} / \mathrm{L}$.

Table 1

Characteristics of patients with Felty's syndrome

\begin{tabular}{|ll|}
\hline Clinical and biological features & \\
\hline Number of patients & 25 \\
\hline No. female/no. male & $19 / 6$ \\
\hline Age $(\mathrm{y})$ at FS diagnosis, median (range) & $54(30-79)$ \\
\hline Duration (y) of RA before FS diagnosis, median (range) & $7(0-35)$ \\
\hline RA disease activity (max. DAS28), median (range) & $4.9(2.1-7.01)$ \\
\hline Erosive arthritis & $73 \%(16 / 23)$ \\
\hline RF positive & $92 \%(23 / 25)$ \\
\hline Anti-CCP positive & $96 \%(23 / 24)$ \\
\hline Anti-MCV positive & $100 \%(11 / 11)$ \\
\hline Splenomegaly & $83 \%(19 / 23)$ \\
\hline Associated autoimmune diseases & $28 \%(7 / 25)$ \\
\hline STAT3 mutation positive & $0 \%(0 / 24)$ \\
\hline STAT5b mutation positive & $0 \%(0 / 24)$ \\
\hline Hematologic features & $1.092(0.42-2.32)$ \\
\hline Leukocytes $\left(\times 10^{9} / \mathrm{L}\right)$, median (range) & $0.413(0.117-1.036)$ \\
\hline Neutrophils $\left(\times 10^{9} / \mathrm{L}\right)$, median (range) & $0.496(0.052-1224.0)$ \\
\hline Lymphocyte $\left(\times 10^{9} / \mathrm{L}\right)$, median (range) & \\
\hline LGLs $\left(\times 10^{9} / \mathrm{L}\right)$, median (range) & \\
\hline
\end{tabular}


A neutrophil count $<0.5 \times 10^{9} / \mathrm{L}$ was observed in 13 of $25(52 \%)$ patients. None of the patients with FS in our cohort had lymphocytosis. The absolute number of lymphocytes in PB ranged from 0.42 to $2.32 \times$ $10^{9} / \mathrm{L}$ with a median of 1.092 . LGL counts $<0.4 \times 10^{9} / \mathrm{L}$ and $>0.4 \times 10^{9} / \mathrm{L}$ were observed in $8(44 \%)$ and $10(56 \%)$ of 18 cases, respectively, but did not exceed $2.0 \times 10^{9} / \mathrm{L}$ in any of the cases.

The results of flow cytometric immunophenotyping of lymphocytes performed in 19 patients are summarized in Table 2. A weakening or absence of CD5 pan T-cell antigen expression on cytotoxic (CD3+/CD8+) T-lymphocytes was the most commonly identified phenotypic abnormality in 13 of 18 (72\%) cases. CD16, CD56, and CD57 expression on cytotoxic T-lymphocytes was found in 1 of 15 (7\%), 1 of $16(6 \%)$, and 10 of $18(56 \%)$ cases, respectively. 
Table 2

Immunophenotypic characteristics of cytotoxic (CD3+/CD8+) T-lymphocytes in patients with Felty's syndrome

\begin{tabular}{|c|c|c|c|c|c|c|}
\hline Case No. & $\begin{array}{l}\text { Specimen } \\
\text { type }\end{array}$ & CD57+ & $\begin{array}{l}\text { CD5low/ } \\
-\end{array}$ & CD16+ & CD56+ & $\begin{array}{l}\text { Lymphocyte counts with an } \\
\text { aberrant immunophenotype in } \\
\text { blood (in microliters) }\end{array}$ \\
\hline 1. & PB & + & + & + & + & 409 \\
\hline 2. & PB & - & + & - & ND & 214 \\
\hline 3. & PB & - & - & - & - & 0 \\
\hline 4. & BM & + & ND & - & - & ND \\
\hline 5. & PB & + & + & - & - & 250 \\
\hline 6. & PB & - & - & - & - & 0 \\
\hline 7. & PB & + & + & - & - & 107 \\
\hline 8. & PB & + & + & - & - & 229 \\
\hline 9. & PB & + & + & - & - & 129 \\
\hline 10. & PB & - & - & ND & - & 0 \\
\hline 11. & PB & + & - & - & - & 98 \\
\hline 12. & PB & ND & + & ND & ND & 450 \\
\hline 13. & PB & - & - & - & - & 0 \\
\hline 14. & $\begin{array}{l}\mathrm{PB} \text { and } \\
\mathrm{BM}\end{array}$ & + & + & - & - & 202 \\
\hline 15. & PB & - & + & - & ND & 118 \\
\hline 16. & PB & + & + & ND & - & 389 \\
\hline 17. & PB & - & + & - & - & 239 \\
\hline 18. & $\begin{array}{l}\mathrm{PB} \text { and } \\
\mathrm{BM}\end{array}$ & + & + & - & - & 223 \\
\hline 19. & PB & - & + & ND & - & 102 \\
\hline Summary & $\begin{array}{l}18 \mathrm{~PB} \\
3 \mathrm{BM}\end{array}$ & $\begin{array}{l}56 \% \\
(10 / 18) \\
\text { pos. }\end{array}$ & $\begin{array}{l}72 \% \\
(13 / 18) \\
\text { pos. }\end{array}$ & $\begin{array}{l}7 \% \\
(1 / 15) \\
\text { pos. }\end{array}$ & $\begin{array}{l}6 \% \\
(1 / 16) \\
\text { pos. }\end{array}$ & $\begin{array}{l}\text { median } 165.5 \\
\text { (range, } 0-450 \text { ) }\end{array}$ \\
\hline
\end{tabular}


Normal or hypercellular bone marrow resulting from myeloid hyperplasia was revealed in all cases. There were no signs of myelodysplasia. The number of lymphocytes in the bone marrow was not elevated and comprised $3.8-18.4 \%$ of nucleated cells. In 11 of 14 patients bone marrow aspirate differential counts showed a significant reduction in segmented neutrophils, and in 1 patient, they showed a reduction in band and segmented neutrophils. However, in 2 patients, the bone marrow aspirate differential count was normal despite detection of PB neutrophils. A bone marrow immunohistochemical study in 2 of 6 cases showed interstitial clusters and/or linear arrays of intravascular CD8+/granzyme B + lymphocytes.

Splenomegaly was observed in 19 of 23 (83\%) patients. Of these, splenectomy was performed in 2 patients. In both cases, the neutrophil count returned to normal values after the splenectomy and remained so during the entire follow-up (43 and 67 months, respectively). Mutations in the STAT3 gene were not detected in any of the 24 cases with FS, whereas in the group with T-LGLL in the setting of RA, STAT3 gene mutations were found in 22 of 56 patients $(39 \%)(p<0.001)$. No STAT5b gene mutation was detected in any of the 24 patients with FS and the 56 patients with RA-associated T-LGLL.

\section{Discussion}

Historically, LGLL could be readily recognized by reviewing a PB smear. An LGL count of more than $2 \times$ $10^{9} / \mathrm{L}$ (normal LGL count in PB: $0.2-0.4 \times 10^{9} / \mathrm{L}$ ) lasting $>6$ months, was considered a criterion for determining this disease.[12, 22] For T-LGLL, the current diagnostic requirements have lowered this threshold to $>0.4$ or $0.5 \times 10^{9} / \mathrm{L}$ provided that a clonal T-LGL population is found with an appropriate clinical context.[23-25] Recent studies have shown that $49 \%$ of patients with T-LGLL have no absolute lymphocytosis and $36 \%$ of patients have blood LGLs $<1 \times 10^{9} /$ L. [9] As the clinical manifestations of RAassociated T-LGLL are often identical to those in which one would suspect an FS, it may be difficult to differentiate RA-associated T-LGLL with a low LGL count $\left(0.4-2.0 \times 10^{9} / \mathrm{L}\right)$ from FS. Moreover, expansion of LGLs can be detected in patients with FS.[26-28] RA-associated T-LGLL and FS can be distinguished by T-cell clonality determined by assessing the TCR gene rearrangements present in T-LGLL but not in FS. $[1,5,29]$ However, there is considerable discussion regarding the significance of dominant T-cell clones as a hallmark of T-cell malignancy because small populations of clonally expanded T-LGLs are revealed in healthy individuals and in an exuberant reactive response.[30-34] Considering that the difference between RA-associated T-LGLL and FS often depends on a single test with well-known gray areas in interpretation and limitations,[35] it is necessary look for additional distinctions. We can use mutations in STAT3 and STAT5 $b$ genes as molecular markers for T-LGLL diagnostics,[36] but their prevalence in FS and their diagnostic value for differential diagnosis between FS and RA-associated T-LGLL are unclear. In this study, we did not detect STAT3 mutations in any of the 24 cases with FS, as opposed to 22 of 56 patients with RA-associated T-LGLL. Further, no STAT5 $b$ mutation was detected in any FS or RAassociated T-LGLL patient in our cohort.

Savola et al. examined STAT3 and STAT5b mutations in 14 patients with RA and neutropenia.[37] Similar to our patient cohort, they did not find any STAT5 $b$ mutations. However, in contrast to our results, they identified STAT3 mutations in 6 of 14 (43\%) patients. We believe that difference between outcomes 
obtained by Savola et al. and our study can be attributed to different methods of assessing T-cell clonality and the patient selection criteria. We tested T-cell clonality based on the rearrangement of gamma and beta chain-encoding genes by a PCR-based assay, whereas Savola et al. studied the clonality of $T$ cells by flow cytometry using a $V \beta$ kit, covering only $70 \%$ of the $V \beta$ T-cell repertoire. In contrast to Savola et al., we did not include patients with T-cellular clonality in the FS group.

Female prevalence, age at FS diagnosis, and duration of RA prior to FS diagnosis in our series were comparable to the results found in literature. $[4,5,38]$ Overall, in our patient cohort, RA was of moderate activity, even though RA is typically severe in patients with FS. All our patients were seropositive: $\mathrm{RF}+$ /anti-CCP+/anti-MCV + or RF-/anti-CCP+/anti-MCV+. Splenomegaly ranging from massive to detectable only based on abdominal imaging modalities, was detected in $83 \%$ of patients. SS was diagnosed in our study in $28 \%$ of patients, which is significantly less than in the FS patient cohorts reported by other authors: 48\% (Sienknecht et al.), 69\% (Barnes et al.), and 53\% (Campion et al.). [2, 3, 39]

In our study, low count expansion of LGLs $\left(0.4-2.0 \times 10^{9} / \mathrm{L}\right)$ in PB was detected in $56 \%$ of cases, but did not exceed $2.0 \times 10^{9} / \mathrm{L}$ and the bone marrow aspirate differential count showed no increase in lymphocytes. Flow cytometric immunophenotyping studies play an important role in the diagnosis of TLGLLs. The expression of CD57 and CD16 antigens, one or both of which are detected in the vast majority of T-LGLL cases, was found on cytotoxic T-lymphocytes in only $56 \%$ and $7 \%$ of our cases, respectively. In contrast, aberrant expression of CD5 was the most common finding in our patient group. This abnormality is frequently associated with T-LGLL, but is also found in T-cell reactive expansion.[41, 42] Bone marrow involvement is present in at least $75 \%$ of T-LGLL cases, although it is often subtle and difficult to detect. Specific criteria have been proposed for the diagnosis of T-LGLL in bone marrow sections using immunohistochemistry.[42; 43] However, as reported by Burks et al., there are probably no distinctive features in bone marrow biopsies that would separate T-LGLL from FS.[5] In 2 patients with FS in our cohort, immunohistochemical studies also revealed that bone marrow infiltration by cytotoxic Tlymphocytes was indistinguishable from T-LGLL lesions.

The pathogenesis of neutropenia in FS has not yet been fully studied and seems to be multifactorial. In 12 of 14 cases in our study, the bone marrow aspirate differential count fit into the expected consequence of peripheral destruction/sequestration of neutrophils. Although the role of splenic sequestration/destruction in neutropenia pathogenesis is not supported by all studies,[5] splenectomy produces a long-term hematologic response in $80 \%$ of patients with FS. [44] We also observed persistent recovery of neutrophil levels after splenectomy in 2 of our patients with FS and massive splenomegaly.

\section{Limitations}

We are aware of some limitations concerning our study design. Due to the retrospective design of the study, some of the data were incomplete. Additionally, we used of allele-specific TaqMan real-time PCR rather than Sanger sequencing to detect somatic point mutations in STAT3 and STAT5b genes. A set of primers for most common mutations in STAT3 and STAT5b genes was developed. Even though this 
approach provides much higher sensitivity compared to Sanger sequencing, some rare mutations, not covered by the developed primers, could not be identified.

\section{Conclusion}

In conclusion, we did not detect STAT3 and STAT5b gene mutations in any of the 24 FS cases in this study, whereas STAT3 gene mutations were found in 22 of 56 patients (39\%) with T-LGLL in RAassociated T-LGLL $(p<0.001)$. Although further data are required, our results suggest that identifying STAT3 mutations in patients with clinical pattern resembling FS may be a counterargument to make this diagnosis and that careful patient evaluation is required to exclude RA-associated T-LGLL.

\section{Abbreviations}

FS: Felty's syndrome; RA:rheumatoid arthritis; T-LGLL:T-cell large granular lymphocytic leukemia; LGLs:large granular lymphocytes; STAT:signal transducer and activator of transcription; RF:rheumatoid factor; anti-CCP:antibodies against cyclic citrullinated peptides; anti-MCV:antibodies against mutated citrullinated vimentin; DAS28:Disease Activity Score derivative for 28 joints; CD:cluster of differentiation; TCR:T-cell receptor; PCR:polymerase chain reaction; AS:allele-specific; WT:wild type; MT:mutated type; PB:peripheral blood; BM:bone marrow; ND:not done

\section{Declarations}

\section{Acknowledgments and affiliations}

We would like to thank Editage (www.editage.com) for English language editing.

\section{Authors' contributions}

V.R.G. substantially contributed to the conception of the work, acquisition, analysis, and interpretation of data; made a draft of the work; approved the final version of the work for publication; and agreed to be responsible for all aspects of the work. Y.V.S., N.A.K., V.I.V., N.A.P., N.V.R., and A.B.S. substantially contributed to the acquisition, analysis, and interpretation of data for the work; critically revised the work for important intellectual content; approved the final version of the work for publication; and agreed to be responsible for all aspects of the work.

Funding: This study did not receive any funding support.

\section{Availability of data and materials}

All data generated or analyzed during this study are included in this article.

\section{Ethics approval and consent to participate}


The study was approved by the V.A. Nasonova Research Institute of Rheumatology Ethics Committee (protocol \#17 on the 20-02-2020) and was conducted in accordance with the Declaration of Helsinki of 1975 , as revised in 2008 . Written informed consent was given by all participants included in the study.

\section{Consent for publication}

Not applicable.

\section{Competing interest statement}

The authors declare that they have no conflicts of interest regarding the publication of this study.

\section{References}

1. Balint GP, Balint PV. Felty's syndrome. Best Pract Res Clin Rheumatol. 2004;18:631-45.

2. Campion G, Maddison PJ, Goulding N, James I, Ahern MJ, Watt I, et al. The Felty syndrome: a casematched study of clinical manifestations and outcome, serologic features, and immunogenetic associations. Med (Baltim). 1990;69:69-80.

3. Sienknecht CW, Urowitz MB, Pruzanski W, Stein HB. Felty's syndrome. Clinical and serological analysis of 34 cases. Ann Rheum Dis. 1977;36:500-7.

4. Goldberg J, Pinals RS. Felty syndrome. Semin Arthritis Rheum. 1980;10:52-65.

5. Burks EJ, Loughran TP Jr. Pathogenesis of neutropenia in large granular lymphocyte leukemia and Felty syndrome. Blood Rev. 2006;20:245-66.

6. Kay J. Clinical manifestations and diagnosis of Felty syndrome. In: UpToDate, St Clair EW, editor, UpToDate, Waltham, MA, (Accessed on Mar 11, 2020).

7. Morice WG, Kurtin PJ, Leibson PJ, Tefferi A, Hanson CA. Demonstration of aberrant T-cell and natural killer-cell antigen expression in all cases of granular lymphocytic leukaemia. Br J Haematol. 2003;120:1026-36.

8. Lundell R, Hartung L, Hill S, Perkins SL, Bahler DW. T-cell large granular lymphocyte leukemias have multiple phenotypic abnormalities involving pan-T-cell antigens and receptors for $\mathrm{MHC}$ molecules. Am J Clin Pathol. 2005;124:937-46.

9. Bareau B, Rey J, Hamidou M, Donadieu J, Morcet J, Reman O, et al. Analysis of a French cohort of patients with large granular lymphocyte leukemia: a report on 229 cases. Haematologica. 2010;95:1534-41.

10. Sanikommu SR, Clemente MJ, Chomczynski P, Afable MG 2nd, Jerez A, Thota S, et al. Clinical features and treatment outcomes in large granular lymphocytic leukemia (LGLL). Leuk Lymphoma. 2018;59:416-22.

11. Schwaneck EC, Renner R, Junker L, Einsele H, Gadeholt O, Geissingeret E, et al. Prevalence and characteristics of persistent clonal T cell large granular lymphocyte expansions in rheumatoid arthritis: a comprehensive analysis of 529 patients. Arthritis Rheumatol. 2018;70:1914-22. 
12. Loughran TP Jr. Clonal diseases of large granular lymphocytes. Blood. 1993;82:1-14.

13. Koskela HL, Eldfors S, Ellonen P, van Adrichem AJ, Kuusanmäki H, Andersson El, et al. Somatic STAT3 mutations in large granular lymphocytic leukemia. N Engl J Med. 2012;366:1905-13.

14. Jerez A, Clemente MJ, Makishima H, Koskela H, Leblanc F, Peng Ng K, et al. STAT3 mutations unify the pathogenesis of chronic lymphoproliferative disorders of NK cells and T-cell large granular lymphocyte leukemia. Blood. 2012;120:3048-57.

15. Fasan A, Kern W, Grossmann V, Haferlach C, Haferlach T, Schnittger S. STAT3 mutations are highly specific for large granular lymphocytic leukemia. Leukemia. 2013;27:1598-600.

16. Shi M, He R, Feldman AL, Viswanatha DS, Jevremovic D, Chen D, et al. STAT3 mutation and its clinical and histopathologic correlation in T-cell large granular lymphocytic leukemia. Hum Pathol. 2018;73:74-81.

17. Rajala HL, Eldfors $S$, Kuusanmaki $H$, van Adrichem AJ, Olson T, Lagström S, et al. Discovery of somatic STAT5b mutations in large granular lymphocytic leukemia. Blood. 2013;121:4541-50.

18. Liu X, Loughran TP Jr. The spectrum of large granular lymphocyte leukemia and Felty's syndrome. Curr Opin Hematol. 2011;18:254-9.

19. Schrenk KG, Krokowski M, Feller AC, Bernhard V, Mügge LO, Oelzner P, et al. Clonal T-LGL population mimicking leukemia in Felty's syndrome - part of a continuous spectrum of T-LGL proliferations? Ann Hematol. 2013;92:985-7.

20. Aletaha D, Neogi T, Silman AJ, Funovits J, Felson DT, Bingham CO 3rd, et al. 2010 rheumatoid arthritis classification criteria: an American College of Rheumatology/European League Against Rheumatism collaborative initiative [published correction appears in Ann Rheum Dis. 2010;69:1892]. Ann Rheum Dis. 2010;69:1580-1588.

21. van Dongen JJ, Langerak AW, Bruggemann M, Evans PA, Hummel M, Lavender FL, et al. Design and standardization of PCR primers and protocols for detection of clonal immunoglobulin and T-cell receptor gene recombinations in suspect lymphoproliferations: report of the BIOMED-2 Concerted Action BMH4-CT98-3936. Leukemia. 2003;17:2257-317.

22. Semenzato G, Pandolfi F, Chisesi T, De Rossi G, Pizzolo G, Zambello R, et al. The lymphoproliferative disease of granular lymphocytes. A heterogeneous disorder ranging from indolent to aggressive conditions. Cancer. 1987;60:2971-8.

23. Semenzato G, Zambello R, Starkebaum G, Oshimi K, Loughran TP Jr. The lymphoproliferative disease of granular lymphocytes: updated criteria for diagnosis. Blood. 1997;89:256-60.

24. Moignet A, Lamy T. Latest advances in the diagnosis and treatment of large granular lymphocytic leukemia. Am Soc Clin Oncol Educ Book. 2018;38:616-25.

25. Cheon H, Dziewulska KH, Moosic KB, Olson KC, Gru AA, Feith DJ, et al. Advances in the diagnosis and treatment of large granular lymphocytic leukemia. Curr Hematol Malig Rep. 2020;15:103-12.

26. Barton JC, Prasthofer EF, Egan ML, Heck LW Jr, Koopman WJ, Grossi CE. Rheumatoid arthritis associated with expanded populations of granular lymphocytes. Ann Intern Med. 1986;104:314-23. 
27. Bowman SJ, Geddes GC, Corrigall V, Panayi GS, Lanchbury JS. Large granular lymphocyte expansions in Felty's syndrome have an unusual phenotype of activated CD45RA + cells. Br J Rheumatol. 1996;35:1252-5.

28. Bowman SJ, Bhavnani M, Geddes GC, Corrigall V, Boylston AW, Panayi GS, et al. Large granular lymphocyte expansions in patients with Felty's syndrome: analysis using anti-T cell receptor $\mathrm{V}$ betaspecific monoclonal antibodies. Clin Exp Immunol. 1995;101:18-24.

29. Shah A, DiehI LF, St Clair EW. T cell large granular lymphocyte leukemia associated with rheumatoid arthritis and neutropenia. Clin Immunol. 2009;132:145-52.

30. Posnett DN, Sinha R, Kabak S, Russo C. Clonal populations of T cells in normal elderly humans: the T cell equivalent to "benign monoclonal gammapathy". J Exp Med. 1994;179:609-18.

31. Delfau-Larue MH, Laroche L, Wechsler J, Lepage E, Lahet C, Asso-Bonnet M, et al. Diagnostic value of dominant T-cell clones in peripheral blood in 363 patients presenting consecutively with a clinical suspicion of cutaneous lymphoma. Blood. 2000;96:2987-92.

32. Dippel E, Klemke D, Hummel M, Stein H, Goerdt S. T-cell clonality of undetermined significance. Blood. 2001;98:247-8.

33. Bigouret V, Hoffmann T, Arlettaz L, Villard J, Colonna M, Ticheli A, et al. Monoclonal T-cell expansions in asymptomatic individuals and in patients with large granular leukemia consist of cytotoxic effector T cells expressing the activating CD94:NKG2C/E and NKD2D killer cell receptors. Blood. 2003;101:3198-204.

34. Sidorova YV, Sychevskaya KA, Chernova NG, Julhakyan HL, Smirnova SJ, Ryzhikova NV, et al. High Incidence of Clonal CD8 + T-cell Proliferation in Non-malignant Conditions May Reduce the Significance of T-cell Clonality Assay for Differential Diagnosis in Oncohematology. Clin Lymphoma Myeloma Leuk. 2020;20:203-8.

35. Groenen PJTA, van Raaij A, van Altena MC, Rombout PM, van Krieken JMH. A practical approach to diagnostic Ig/TCR clonality evaluation in clinical pathology. J Hematopathol. 2012;5:17-25.

36. Rajala HL, Porkka K, Maciejewski JP, Loughran TP Jr, Mustjoki S. Uncovering the pathogenesis of large granular lymphocytic leukemia-novel STAT3 and STAT5b mutations. Ann Med. 2014;46:11422.

37. Savola P, Brück O, Olson T, Kelkka T, Kauppi MJ, Kovanen PE, et al. Somatic STAT3 mutations in Felty syndrome: an implication for a common pathogenesis with large granular lymphocyte leukemia. Haematologica. 2018;103:304-12.

38. Rosenstein ED, Kramer N. Felty's and pseudo-Felty's syndromes. Semin Arthritis Rheum. 1991;21:129-42.

39. Barnes CG, Turnbull AL, Vernon-Roberts B. Felty's syndrome. A clinical and pathological survey of 21 patients and their response to treatment. Ann Rheum Dis. 1971;30:359-74.

40. Toga A, Wada T, Sakakibara Y, Mase S, Araki R, Tone Y, et al. Clinical significance of cloned expansion and CD5 down-regulation in Epstein-Barr Virus (EBV)-infected CD8 + T lymphocytes in EBV-associated hemophagocytic lymphohistiocytosis. J Infect Dis. 2010;201:1923-32. 
41. Wada T. Downregulation of CD5 and dysregulated CD8 + T-cell activation. Pediatr Int. 2018;60:77680.

42. Morice WG, Kurtin PJ, Tefferi A, Hanson CA. Distinct bone marrow findings in T-cell granular lymphocytic leukemia revealed by paraffin section immunoperoxidase stains for CD8, TIA-1, and granzyme B. Blood. 2002;99:268-74.

43. Dogan A, Morice WG. Bone marrow histopathology in peripheral T-cell lymphomas. $\mathrm{Br} \mathrm{J}$ Haematol. 2004;127:140-54.

44. Rashba EJ, Rowe JM, Packman CH. Treatment of the neutropenia of Felty syndrome. Blood Rev. 1996;10:177-84.

\section{Supplementary Files}

This is a list of supplementary files associated with this preprint. Click to download.

- Supplement1.doc

- Supplement1.doc

- SupplementaryTable1.doc.doc

- SupplementaryTable1.doc.doc 